\title{
PENGEMBANGAN MEDIA PEMBELAJARAN VIDEO TUTORIAL PADA MATA KULIAH GASTRONOMI
}

\author{
Elida $^{1}$, Wiwik Gusnita ${ }^{2}$, Dikki Zulfikar ${ }^{3}$ \\ Program Studi Pendidikan Kesejahteraan Keluarga \\ Fakultas Pariwisata Dan Perhotelan \\ Universitas Negeri Padang \\ email : elidampd@gmail.com,wiwikgusnita76@yahoo.com, \\ dikkizulfikar@fpp.unp.ac.id
}

\begin{abstract}
Abstrak
Penelitian ini bertujuan mengembangkan media video pembelajaran untuk mata kuliah gastronomi pada mahasiswa jurusan pendidikan kesejahteraan keluarga, mengetahui validitas media video pembelajaran untuk mata kuliah gastronomi pada mahasiswa jurusan pendidikan kesejahteraan keluarga, mengetahui praktikalitas media video pembelajaran untuk mata kuliah gastronomi pada mahasiswa jurusan pendidikan kesejahteraan keluarga

Hasil penelitian ini menunjukkan Media Pembelajaran video tutorial mata kuliah gastronomi pada mahasiswa semester 5 jurusan pendidikan kesejahteraan keluarga memiliki kriteria Valid dengan nilai Aiken's V 0,75, Produk Media Pembelajaran video tutorial mata kuliah gastronomi yang dikembangkan untuk mahasiswa semester 5 jurusan pendidikan kesejahteraan keluarga memenuhi syarat dan layak digunakan berdasarkan validasi ahli materi meliputi kelayakan isi dengan nilai Aiken's V 0,78 pada kriteria Valid, kelayakan penyajian dengan nilai Aiken's V \% 0,73 pada kriteria Valid, aspek bahasa dengan nilai Aiken's V 0,78 pada kriteria Valid, praktikalitas dilihat dari pengujian dosen mendapat nilai praktis sebesar $78,75 \%$.
\end{abstract}

Kata Kunci: Media Pembelajaran, Video Tutorial, Mata Kuliah Gastronomi

\begin{abstract}
This research aims to develop media instructional videos for subjec gastronomy to students majoring in family welfare education, determine the validity media instructional videos for gastronomy to students majoring in family welfare education, knowing the effectiveness instructional video media for subject gastronomy to students majoring in family welfare education, knowing the practicalities media instructional videos for subject gastronomy to students majoring in family welfare education.

The results of this study indicate Media Instructional Videos Tutorial Product on this subject in fifth semester of students majoring in family welfare education criteria Valid values Aiken's V 0.75, Media Instructional Videos Tutorial Product on this subject in fifth semester of students majoring in family welfare education qualified and fit for use based on the expert validation material includes feasibility content with value Aiken's V 0.78 Valid criteria, eligibility Aiken's presentation with a value of $0.73 \mathrm{~V} \%$ on Valid criteria, aspects of language with Aiken's value V 0.78 Valid criteria, seen from the practicalities of testing lectures got Good value amounted to $78.75 \%$,
\end{abstract}

Keywords: Learning Media, Video Tutorials, Gastronomy 


\section{A. Pendahuluan}

Indikator utama suatu pergurua tinggi dalam mencapai kesuksesan yaitu kualitas lulusannya. Kesuksesan sebuah negara dalam menghadapi revolusi industri 4.0 erat kaitannya dengan inovasi yang diciptakan oleh sumber daya yang berkualitas, sehingga Perguruan

Tinggi wajib dapat menjawab tantangan untuk menghadapi kemajuan teknologi dan persaingan dunia kerja di era globalisasi.

Menciptakan sumber daya yang inovatif, kreatif dan adaptif terhadap teknologi, diperlukan juga suatu konsep pembelajaran yang dapat menyesuaikan terhadap hal yang terkait erat dengan tehnologi informasi, internet serta komputerisasi, maka untuk itu pula dalam pelaksanaanya proses pembelajaran di perguruan tinggi dibutuhkan inovasi dalam pembelajaran baik berupa metode, kurikulum maupun media pembelajaran nya sehinga hal ini dapat menjawab tantangan relovolusi industry 4.0 .

Mata kuliah gastronomi merupakan salah satu mata kuliah pada jurusan Ilmu Kesejahteraan Keluarga pada semester 5. Mata kuliah memiliki bobot sebanyak 3 sks dan merupakan mata kuliah lanjutan dari beberapa mata kuliah di semester semester sebelumnya. Setelah mengikuti mata kuliah ini kedepanya mahasiswa diharapkan memiliki kompetensi terampil mengadakan inovasi dan improvisasi pada pengolahan dan penyajian makanan dan penganan sehingga dapat dijadikan aset wisata.

Berdasarkan permasalahan di atas, untuk menjawab tantangan era revolusi industry 4.0, maka dibutuhkanlah inovasi-inovasi dalam pembelajaran mata kuliah Gastronomi inovasinya berupa media pembelajaran sehingga dapat memotivasi mahasiswa untuk belajar lebih menyenangkan serta dapat mempermudah mahasiswa dalam menyerap pengetahuan dan keterampilan dalam bidang gastronomi. Dengan adanya inovasi dalam pembelajaran baik dalam hal metode maupun media pembelajaran, diharapkan mahasiswa dapat termotivasi sehingga mampu menguasai materi gastronomi dalam waktu yang singkat serta dapat bersaing dalam dunia revolusi industry 4.0.

\section{B. Metode Penelitian}

Berdasarkan latar belakang dan rumusan masalah dalam penelitian ini, maka jenis penelitian yang akan dilakukan adalah penelitian pengembangan atau development research. Model pengembangan yang digunakan adalah model Instruksional Development Institute 
(IDI). Menurut (Gustafson \& Brach, 1997), IDI menerapkan prinsip-prinsip pendekatan sistem yang meliputi tiga tahapan, yaitu penemuan (define) atau analisis kebutuhan, pengembangan (develop), dan evaluasi (evaluate).

Produk pengembangan media pembelajaran media pembelajaran video tutorial mata kuliah gastronomi merupakan materi pembelajaran yang telah dikembangkan dengan memperhatikan aspek pembelajaran dan media sebagai prinsip desain pesan pembelajaran. Penelitian pengembangan produk yang dilakukan ini diarahkan untuk menghasilkan suatu produk berupa media pembelajaran video tutorial untuk mahasiswa jurusan Pendidikan kesejahteraan keluarga pada mata kuliah gastronomi yang digunakan untuk meningkatkan proses pembelajaran maupun kompetensi mahasiswa. Oleh sebab itu proses penelitian ini dilakukan dan diawali dengan (1) studi pendahuluan, (2) kemudian mendesain media pembelajaran, (3) melakukan validasi produk, dan (4) melakukan revisi dan penyempurnaan berdasarkan analisis data validasi dari ahli materi, ahli desain pembelajaran dan ahli rekayasa perangkat lunak yang dilanjutkan dengan uji coba perorangan, uji coba kelompok kecil, dan uji coba lapangan sehingga dihasilkan media pembelajaran yang layak digunakan sesuai dengan karakteristik mata kuliah dan mahasiswa sebagai pengguna.

Aspek yang direvisi dan disempurnakan berdasarkan analisis data dan uji coba serta masukan dari ahli materi, ahli desain pembelajaran, ahli rekayasa perangkat lunak dan mahasiswa selaku pengguna media pembelajaran interaktif ini, bertujuan untuk menggali beberapa aspek yang lazim dalam proses pengembangan suatu produk. Variabel-variabel media pembelajaran memiliki nilai rata-rata Sangat Sesuai. Adapun variabel media pembelajaran yang dinilai meliputi kelayakan isi, penyajian, kebahasaan, dan kegrafikan.

Manfaat dalam penggunaan media pembelajaran video tutorial mata kuliah gastronomi adalah sebagai berikut: (1) materi mudah dipahami karena konsep yang disajikan direncanakan untuk mempermudah mahasiswa dan sistematis, (2) belajar lebih cepat dan menarik sehingga tidak menimbulkan kebosanan karena dilengkapi dengan gambar-gambar bergerak dan music pengiring, (3) media pembelajaran interaktif ini juga dapat digunakan sebagai alternatif media pembelajaran secara individual.

\section{Hasil Dan Pembahasan}

Penilaian validitas oleh ahli materi terhadap pengembangan media pembelajaran video tutorial pada mata kuliah gastronomi dilakukan oleh beberapa orang yang meliputi dosen di bidang boga dan ketua Indonesian Chef Assosiation Sumatera Barat. Penilaian validasi tersebut disajikan dalam table 1 berikut: 
Tabel 1. Aiken`s V Media Pembelajaran Video Tutorial Mata kuliah Gastronomi Oleh Ahli Materi

\begin{tabular}{|c|l|c|c|}
\hline NO & \multicolumn{1}{|c|}{ Aspek yang dinilai } & Aiken`s V & Kriteria \\
\hline 1 & Kelayakan isi & 0,78 & Valid \\
\hline 2 & Penyajian & 0,73 & Valid \\
\hline 3 & kebahasaan & 0,75 & Valid \\
\hline \multicolumn{2}{r|r}{ Rata-rata } & 0,75 & Valid \\
\hline
\end{tabular}

Penilaian validalitas oleh Media Pembelajaran terhadap pengembangan media pembelajaran video tutorial pada mata kuliah gastronomi dilakukan oleh beberapa orang ahli desain pembelajaran. Penilaian validasi tersebut disajikan dalam table 2 berikut:

Tabel 2. Aiken`s V Media Pembelajaran Video Tutorial Pada Mata Kuliah Gastronomi Oleh Ahli Media Pembelajaran

\begin{tabular}{|c|l|c|c|}
\hline NO & \multicolumn{1}{|c|}{ Aspek yang dinilai } & Aiken`s V & Kriteria \\
\hline 1 & Kualitas desain pembelajaran & 0,73 & Valid \\
\hline 2 & Kualitas desain informasi & 0,73 & Valid \\
\hline 3 & Kualitas desain interaksi & 0,77 & Valid \\
\hline \multicolumn{2}{r|}{ Rata-rata } & 0,74 & Valid \\
\hline
\end{tabular}

Uji praktikalitas dilakukan oleh dosen dosen bidang boga dengan melihat respons mereka dalam penggunaan media video tutorial yang dibuat. Hasil uji praktikalitas tersebut disajikan dalam table 3 berikut:

Table 3 Persentase Rata Rata Hasil Penilaian Respons Dosen Terhadap Media Pembelajaran Video Tutorial Mata Kuliah Gastronomi

\begin{tabular}{|c|l|c|c|}
\hline NO & \multicolumn{1}{|c|}{ Kategorisasi } & Persentase rata rata & Kriteria \\
\hline 1 & Kemudahan penggunaan media & 72,50 & Praktis \\
\hline 2 & Efektifitas waktu & 82,50 & Sangat Praktis \\
\hline 3 & Pengiterprestasian media & 80,00 & Sangat Praktis \\
\hline 4 & Ekivalen & 80,00 & Sangat Praktis \\
\hline \multicolumn{2}{|r|}{ Rata-rata } & 78,75 & Praktis \\
\hline
\end{tabular}


Uji praktikalitas dilakukan yang dilakukan oleh mahasiswa perorangan dengan melihat respons mereka dalam penggunaan media video tutorial yang dibuat. Hasil uji praktikalitas tersebut disajikan dalam table 4 berikut:

Table 4 Persentase Rata-rata Hasil Penilaian Terhadap Media Pembelajaran Video Tutorial Mata Kuliah Gastronomi Pada Uji Perorangan

\begin{tabular}{|c|l|c|c|}
\hline NO & \multicolumn{1}{|c|}{ Kategorisasi } & Persentase rata rata & Kriteria \\
\hline 1 & Aspek kemudahan media & 74,44 & Praktis \\
\hline 2 & Aspek waktu yang diperlukan & 73,33 & Praktis \\
\hline 3 & Aspek dayatari media & 74,67 & Praktis \\
\hline \multicolumn{2}{|c|}{ Rata-rata } & 74,15 & Praktis \\
\hline
\end{tabular}

Uji praktikalitas dilakukan yang dilakukan oleh mahasiswa pada kelompok kecil dengan melihat respons mereka dalam penggunaan media video tutorial yang dibuat. Hasil uji praktikalitas tersebut disajikan dalam table 5 berikut:

Table 5 Persentase Rata-rata Hasil Penilaian Terhadap Media Pembelajaran Video Tutorial Mata Kuliah Gastronomi Pada Uji Kelompok Kecil

\begin{tabular}{|c|l|c|c|}
\hline NO & \multicolumn{1}{|c|}{ Kategorisasi } & Persentase rata rata & Kriteria \\
\hline 1 & Aspek kemudahan media & 76,67 & Praktis \\
\hline 2 & Aspek waktu yang diperlukan & 77,78 & Praktis \\
\hline 3 & Aspek dayatarik media & 75,11 & Praktis \\
\hline \multicolumn{2}{r|}{ Rata-rata } & 76,52 & Praktis \\
\hline
\end{tabular}

Uji praktikalitas dilakukan yang dilakukan oleh mahasiswa pendidikan kesejahteraan keluarga dengan melihat respons mereka dalam penggunaan media video tutorial yang dibuat. Hasil uji praktikalitas tersebut disajikan dalam table 6 berikut:

Table 6 Persentase Rata-rata Hasil Penilaian Terhadap Media Pembelajaran Video Tutorial Mata Kuliah Gastronomi Pada Uji Lapangan Mahasiswa pendidikan kesejahteraan keluarga

\begin{tabular}{|c|l|c|c|}
\hline NO & Kategorisasi & Persentase rata rata & Kriteria \\
\hline 1 & Aspek kemudahan media & 77,83 & Praktis \\
\hline 2 & Aspek waktu yang diperlukan & 79,50 & Praktis \\
\hline 3 & Aspek dayatarik media & 79,80 & Praktis \\
\hline \multicolumn{2}{r|}{ Rata-rata } & 79,04 & Praktis \\
\hline
\end{tabular}




\section{Simpulan Dan Saran}

\section{Kesimpulan}

Berdasarkan hasil penelitian dan pembahasan maka dapat diambil kesimpulan sebagai berikut:

a. Media Pembelajaran video tutorial mata kuliah gastronomi mahasiswa jurusan pendidikan kesejahteraan keluarga memiliki kriteria praktis dengan persentase sebesar 79,02\%.

b. Produk Media Pembelajaran video tutorial mata kuliah gastronomi yang dikembangkan untuk mahasiswa jurusan pendidikan kesejahteraan keluarga memenuhi syarat dan layak digunakan berdasarkan validasi ahli materi meliputi kelayakan isi dengan nilai Aiken's V 0,78 pada kriteria Valid, kelayakan penyajian dengan nilai Aiken's V \% 0,73 pada kriteria Valid, aspek bahasa dengan nilai Aiken's V 0,78 pada kriteria Valid

c. Praktikalitas penggunaan media pembelajaran video tutorial mata kuliah gastronomi pada mahasiswa jurusan pendidikan kesejahteraan keluarga dilihat dari pengujian dosen mendapat nilai praktis sebesar $78,75 \%$.

\section{Saran}

Berdasarkan penelitian yang dilakukan, maka disarankan hal-hal sebagai berikut:

a. Media pembelajaran video tutorial mata kuliah gastronomiini, agar dapat digunakan dalam proses pembelajaran sehingga dapat membantu mahasiswa untuk memahami materi pembelajaran, dan mampu mengaitkan pembelajaran yang diperoleh dengan kehidupan sehari-hari.

b. Mengingat hasil penelitian pengembangan media pembelajaran video tutorial mata kuliah gastronomi ini masih memungkinkan dipengaruhi oleh faktor-faktor yang belum mampu terkendali, maka perlu kiranya dilakukan penelitian lebih lanjut pada sampel yang lebih banyak dan luas

\section{DAFTAR RUJUKAN}

Departemen Perdagangan Republik Indonesia. 2008. Rencana Pengembangan Ekonomi Kreatif Tahun 2009 - 2025

Depdiknas. 2004. Rencana Strategis Depdiknas 2004-2009 
Zulfikar, D. (2018, October 17). Pengembangan Media Pembelajaran Video Tutorial Berbahasa Inggris Pengolahan Makanan Kontinental Pada Sekolah Menengah Kejuruan Program Keahlian Jasa Boga. Retrieved from osf.io/k6e5z

Prosser, C.A. \& Quigley, T.H.1950. Vocational Education in a Democracy. Revised Edition. Chicago: American Technical Society

Robbins, Stephen P, Coulter, Mary, 2007. Managemen. New Yersey: Person International Edition

Cheppy,Riyana. 2007. Pedoman Pengembangan Media Video. Jakarta: P3AI UPI.

Daryanto. 2010. Media Pembelajaran. Yogyakarta: Gava Media.

Prihastuti, Ekawatiningsih, Kokom Komariah, Sutriyati Purwanti. 2008. Restoran Jilid 2. Jakarta: Direktorat Pembinaan Sekolah Menegah Kejuruan

Winarno, Surakhmad. 1996. Pengantar Interaksi Mengajar_Belajar (Dasar dan Teknik Metodologi Mengajar). Bandung: Tarsito 